\title{
Purification of Chitinase enzymes from Bacillus subtilis bacteria TV-125, investigation of kinetic properties and antifungal activity against Fusarium culmorum
}

\author{
Merve Senol ${ }^{1}$, Hayrunnisa Nadaroglu ${ }^{2^{*}}$, Neslihan Dikbas $^{1^{*}}$ and Recep Kotan ${ }^{3}$
}

\begin{abstract}
Background: Chitin is the main structural component of cell walls of fungi, exoskeletons of insects and other arthropods and shells of crustaceans. Chitinase enzyme is capable of degrading chitin, and this enzyme can be used as a biological fungicide against phytopathogenic fungi, as well as an insecticide against insect pests.

Methods: In this study, 158 isolates, which were derived from bacteria cultures isolated from leaves and root rhizospheres of certain plants in Turkey, were selected after confirming that they are not phytopathogenic based on the hypersensitivity test performed on tobacco; and antifungal activity test was performed against Fusarium culmorum, which is a pathogenic fungi that cause decomposition of roots of vegetables. Accordingly, chitinase enzyme activity assay was performed on 31 isolates that have an antifungal activity, and among them the isolate of Bacillus subtilis TV-125 was selected, which has demonstrated the highest activity.

Results: Chitinase enzyme was purified by using ammonium sulphate and DEAE-sephadex ion exchange chromatography. Ammonium sulphate precipitation of chitinase enzyme from Bacillus subtilis TV-125 isolate was performed at maximum range of $0-20 \%$, and $28.4-$ fold purification was obtained with a $13.4 \%$ of yield. Optimum activity of the purified enzyme was observed at $\mathrm{pH} 4.0$ and at $50^{\circ} \mathrm{C}$ of temperature. In addition, it was identified that Bacillus subtilis TV-125A isolate retains $42 \%$ of its activity at $80^{\circ} \mathrm{C}$ temperature.
\end{abstract}

Conclusion: In the last phase of the study, chitinase enzyme purified from Bacillus subtilis TV-125A was tested on four fungal agents, although all the results were positive, it was particularly effective on F. culmorum according to the findings.

Keywords: Chitinase, Purification, Antifungal activity, Fusarium culmorum, Bacillus subtilis

\section{Background}

Chitin ((1,4)-2-acetamide-2-deoxy-beta-D-glucan) is a polysaccharide created by beta,1-4 bonding of $\mathrm{N}$-acetyl glucosamine residues. Functional properties and physiological activities of chitin oligomers depend on molecular weight and chain length mostly [1]. Although most of the natural polysaccharides are either neutral or acidic, chitin is basic $[2,3]$.

\footnotetext{
*Correspondence: hnisa25@atauni.edu.tr; neslidikbas@atauni.edu.tr 2Department of Food Technology, Erzurum Vocational Training School, Ataturk University, 25240 Erzurum, Turkey

'Department of Biotechnology, Faculty of Agriculture, Ataturk University, 25240 Erzurum, Turkey

Full list of author information is available at the end of the article
}

Chitin is the main component of most insects' cuticles and peritrophic membranes that protect intestines of insects. Pathogenic bacteria that infect intestines are required to pass this chitin-rich barrier first [4-6]. At the same time, chitin is present in tracheal tubes of insects, on their upper skin and muscles along with protein and other components [7].

Chitin is hydrolyzed by two types of enzymes, namely chitinase (E.C. 3.2.1.14) and beta- $\mathrm{N}$-acetyl hexosaminidase (E.C. 3.2.1.52) [8].

Bacterial chitinase enzymes have been implicated in protection against parasites in fungi, protozoa and invertebrates, and especially in breakdown of micelles of 
fungal pathogens. In addition, chitinase are involved in the defense mechanisms of plants and vertebrates as well. And, plants produce chitinase enzyme to defend themselves against fungal pathogens [9]. The baculoviruses used in biological control of insect pests produce chitinase for pathogenicity [10]. Chitooligosaccharides are produced via chitinase enzyme. Chitooligosaccharides are substances produced in the plant defense and has a substantial use in medicine. For example, chitohexose and chitoheptose have an antitumor effect. Chitinase obtained from Vibrio alginolyticus produces chitopentose and chitotriose from colloidal chitin [11].

In recent years, it was done some researches related to leaving shellfish to decay. For this purpose, new some products were obtained for recycling waste by utilizing chitinase enzyme with chemical or biological methods. Particularly, the pollution emerged at the bottom of sea and oceans as a result of the death shellfishes is prevented by using microorganisms (Vibrio furnis etc.) that have chitinase enzyme, which decomposes chitin. Moreover, chitinase enzyme has wide range of applications in the food industry, feed industry, cosmetic industry, medical and fertilizer production areas [12].

In this study, first it was aimed to determine antifungal activities of 100 different microorganisms against F. culmorum isolated from cucumber that cause root rot of vegetables as a pathogenic fungi, and also characterization of chitinase enzyme was intended by selecting the strains that have the highest chitinase production capability. In the $2^{\text {nd }}$ phase of the study, purification and characterization of the chitinase enzyme produced extracellularly by using Bacillus subtilis TV-125a bacteria, which was found to have the highest chitinase activity, were aimed; and in the last phase of the study, its antifungal activity was investigated against F. culmorum.

\section{Methods}

Bacteria isolates used in the study

In this study, a total of 158 bacteria isolates were used. These isolates are from the Bacillus megaterium, Bacillus subtilis, Bacillus pumilus, Pseudomonas flourescens, Pseudomonas putida, Bacillus thuringiensis, Paenibacillus macerans, Paenibacillus polymyxa and Pantoea agglomerans species. These bacteria were provided by Assoc. Prof. Dr. Recep Kotan (Atatürk University, Faculty of Agriculture, Department of Crop Protection). Most of the bacterial isolates used have been selected because of their bioagent properties against various plantpathogenic bacteria and fungi. Bacteria species used and total number of isolates from these species are shown in Table 1.
Table 1 The used bacterial strains in this study and the total numbers of isolates of these species

\begin{tabular}{ll}
\hline The used bacterial strains & Total isolates numbers \\
\hline Bacillus megaterium & 46 \\
Bacillus subtilis & 21 \\
Bacillus pumilus & 19 \\
Pseudomonas flourescens & 15 \\
Pseudomonas putida & 15 \\
Bacillus thuringiensis & 11 \\
Paenibacillus macerans & 11 \\
Paenibacillus polymyxa & 10 \\
Pantoea agglomerans & 10 \\
Total & $\mathbf{1 5 8}$
\end{tabular}

\section{Purification of chitinase enzyme from Bacillus subtilis TV-125A}

Chitinase enzyme was partially purified by ammonium sulfate precipitation of Bacillus subtilis TV-125A bacteria. For this purpose, the bacteria homogenate was precipitated by ammonium sulfate precipitation at $0-100 \%$ ranges and chitinase activity of the precipitate and the supernatant was examined to identify the range with the highest activity. The precipitate was dissolved in $0.1 \mathrm{M}$ phosphate buffer ( $\mathrm{pH}: 7.0)$ and dialyzed against the same buffer [13]. The chitinase enzyme was allowed to stand at $-25^{\circ} \mathrm{C}$ in $0.1 \mathrm{M}$ Tris- $\mathrm{HCl}$ buffer ( $\mathrm{pH} 7.0$ ) for further processing.

The dialysed suspension was applied to previously equilibrated DEAE-sephadex ion exchange column $(2.5 \times$ $30 \mathrm{~cm}$ ) with $20 \mathrm{mM}$ sodium sitrate $(\mathrm{pH}: 6.0)$. The column was washed with the same buffer. Then, bound proteins were eluted by applying a gradient to the column from 0 to $1 \mathrm{M} \mathrm{NaCl}$. The fractions were collected as $3 \mathrm{~mL}$, with a $3 \mathrm{~mL} / \mathrm{min}$ flow rate. Protein elution absorbance was spectrophotometrically measured at $280 \mathrm{~nm}$. Involved activities of chitin were measured for all fractions. The fractions with chitinase activity were pooled and it was allowed to stand at $4^{\circ} \mathrm{C}$.

\section{Determining chitinase enzyme activity}

Chitinase enzyme activity was determined using colloidal chitin substrate. After transferring substrate into the medium of the enzyme solution, it was subjected to reaction by incubation at $37^{\circ} \mathrm{C}$ for 30 minutes. Subsequently, after adding staining solutions into the reaction mixture, it was allowed to stand at $80^{\circ} \mathrm{C}$ for 10 minutes, and a measurement with spectrophotometer (PG-T80 Instrument UV-VIS Spectrophotometer) was performed against blind sample that was created by putting distilled, and activity was determined by monitoring absorbance change at $540 \mathrm{~nm}$. 
Table 2 Purification steps of the enzyme chitinase from Bacillus subtilis TV-125A

\begin{tabular}{|c|c|c|c|c|c|c|c|}
\hline \multirow[t]{2}{*}{ Purification steps } & \multirow{2}{*}{$\begin{array}{l}\text { Volume } \\
(\mathrm{mL})\end{array}$} & \multirow{2}{*}{$\begin{array}{l}\text { Activity } \\
\text { (EU/mL) }\end{array}$} & \multicolumn{2}{|c|}{ Total activity } & \multirow{2}{*}{$\begin{array}{l}\text { Protein amount } \\
(\mathrm{mg} / \mathrm{mL})\end{array}$} & \multirow{2}{*}{$\begin{array}{l}\text { Specific activity } \\
\text { (EU/mg) }\end{array}$} & \multirow[t]{2}{*}{ Purificationfold } \\
\hline & & & EU & $\%$ & & & \\
\hline Crude extrat & 50 & 44.95 & 8155.0 & 100 & 6.46 & 6.95 & - \\
\hline $\begin{array}{l}\text { Ammonium sulphate precipitation } \\
(\% 0-20)\end{array}$ & 5 & 255.5 & 1277.5 & 15.7 & 1.64 & 155.79 & 22.4 \\
\hline DEAE Sephadex column & 20 & 55.2 & 1104.0 & 13.4 & 0.28 & 197.14 & 28.4 \\
\hline
\end{tabular}

\section{Determining optimum $\mathrm{pH}$ value of chitinase enzyme}

Using sodium acetate $(\mathrm{pH} 2.0-3.0)$, sodium citrate $(\mathrm{pH} 4.0-$ 6.0), Tris- $\mathrm{HCl}$ ( $\mathrm{pH} 7.0-9.0)$ and Na-carbonate ( $\mathrm{pH} 10-11)$ buffers, chitinase enzyme activity assay was performed at different $\mathrm{pH}$ values ( $\mathrm{pH}$ 2.0-11) to determine the optimum $\mathrm{pH}$ of the chitinase enzyme. Colloidal chitin was used as substrate in the standard activity assay method to perform the measurements.

\section{Determining optimum temperature value of chitinase enzyme}

For determination of optimum temperature of enzyme activity, activity measurements were performed at temperatures of $10-90^{\circ} \mathrm{C}$. For this purpose, standard activity assay method was used. Each experiment was repeated for three times and data were averaged.

\section{Determining protein amount}

Bradford method was used to determine the protein amount. Results were compared to values of standard graphics plotted by using bovine serum albumin, and the total protein values in the samples were calculated. The sensitivity of this method is 1 to $100 \mu \mathrm{g}$ [14].

\section{SDS-PAGE electrophoresis}

In order to determine the number of sub-units of the chitinase enzyme partially purified from Bacillus subtilis TV-125a bacteria, discontinuous sodium dodecyl sulfate gel electrophoresis (SDS-PAGE) was performed by a method stated by Laemmli (1970), in two different acrylamide concentrations with a $3 \%$ stacking gel and $10 \%$ separating gel [15]. Obtained gel image was photographed.

\section{Determination of the antifungal activity of the bacterial isolates in petri dish}

F. culmorum causes rot to roots in vegetables and this disease is commonly seen in all vegetables in Turkey. So, we choose this fungus for antifungal activity. Determination of antifungal properties of 158 bacterial isolates against pathogenic fungi of $F$. culmorum was performed in Potato Dextrose Agar (PDA-Oxoid) nutrient media at $24^{\circ} \mathrm{C}$ under 15 hours of light and 9 hours of dark conditions.

The discs $6 \mathrm{~mm}$ in diameter taken from the pathogenic fungus culture growing on PDA were placed in the center of Petri dishes containing PDA nutrient media. And, bacterial cultures of $1 \times 10^{8}$ cells $/ \mathrm{mL}$ concentration were drawn around these pathogen-inoculated petri dishes. Each bacterium was studied in 3 replications, and the average inhibition zone created by bioagent was identified with the help of the values obtained [16].

\section{Results}

Chitinase (poly-beta-1, 4-[2-acetamido-2-deoxy]- $\delta$-glucoside glycanohydrolase, EC 3.2.1.14), which is the first

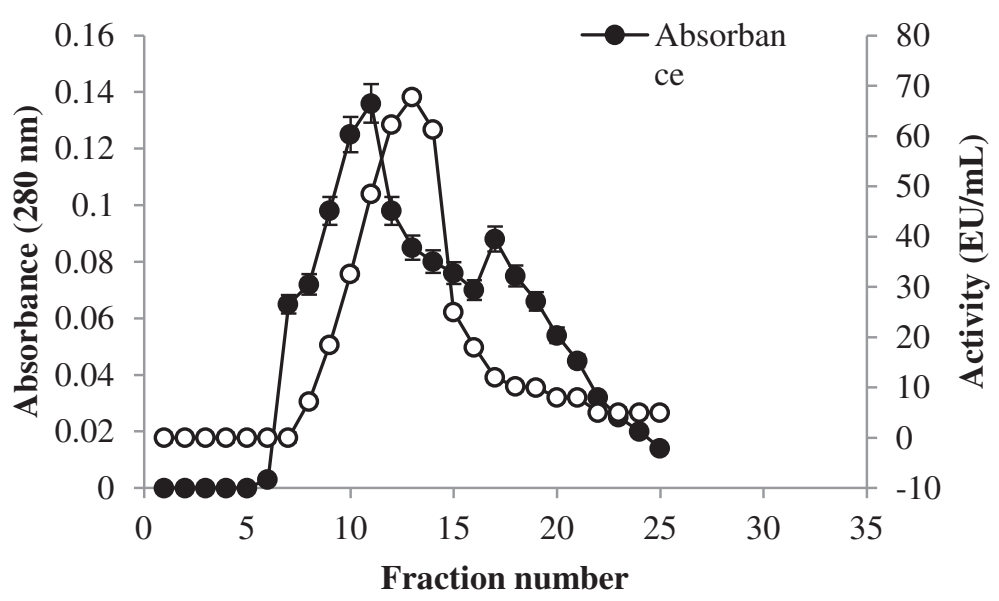

Figure 1 Purification of chitinase enzyme from Bacillus subtilis TV-125A by ion exchange chromatography using DEAE-Sephadex. 


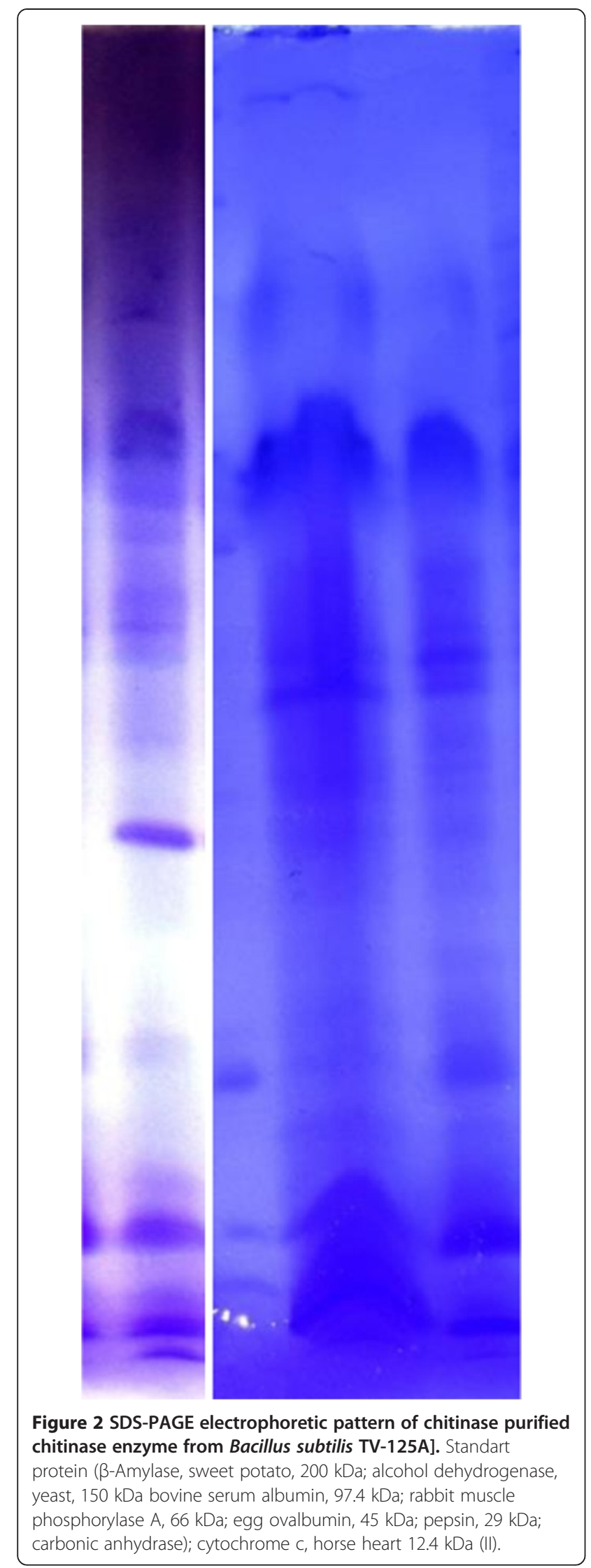

important enzyme of the two types of enzymes, plays a role in hydrolysis of chitin [17].

After centrifugation of chitinase crude extract of the isolate of Bacillus subtilis TV-125, the supernatant was precipitated by $\left(\mathrm{NH}_{4}\right)_{2} \mathrm{SO}_{4}$ precipitation at $0-20,20-40$, $40-60,60-80,80-100 \%$ ranges. The amount of protein, enzyme activity $(\mathrm{EU} / \mathrm{mL})$ and specific activity values determined for samples obtained for each method and step of partial purification steps of the chitinase enzyme derived from Bacillus subtilis TV-125 strains are presented in Table 2. Chitinase enzyme was extracelularly produced from Bacillus subtilis TV-125 and it was purified by using two steps. According to the results, the enzyme obtained from the Bacillus subtilis TV-125 using $0-20 \%\left(\mathrm{NH}_{4}\right)_{2} \mathrm{SO}_{4}$ saturation with 22.4-fold purification and $15.7 \%$ recovery, was subjected to ion-exchange chromatography, which gave one peak with chitinase activity. Passage from DEAE-Sephadex column further purified the enzyme to 28.4-fold with a recovery of $13.4 \%$ and specific activity of $197.14 \mathrm{EU} / \mathrm{mg}$. Chitinase enzyme from Bacillus subtilis TV-125, bacteria elution profiles with anion exchange chromatography was purified, and they were presented in Figure 1.

Sodium dodecyl sulfate polyacrylamide gel electrophoresis (SDS-PAGE)'s results were presended (Figure 2).

The $\mathrm{pH}$ 2.0-11.0 range was tested in order to find optimum $\mathrm{pH}$ value of chitinase enzyme derived and purified from Bacillus subtilis TV-125A. Sodium acetate ( $\mathrm{pH} 2.0$ to 3.0 ), sodium citrate ( $\mathrm{pH} 4.0-6.0)$, Tris ( $\mathrm{pH} 7.0$ to 9.0) and Sodium carbonate ( $\mathrm{pH}$ 10.0-11.0) buffers were used in order to create different $\mathrm{pH}$ media (Figure 3).

As a result of the tests, optimum $\mathrm{pH}$ value of chitinase enzyme partially purified from Bacillus subtilis TV-125A was determined as 4.0, as shown in Figure 3. Not much decrease was observed in the enzyme activity assay performed for pure enzyme In the range of $\mathrm{pH} 4.0$ to 11.0. It was found that activity of the enzyme was retained by $71 \%$ at $\mathrm{pH}$ 11.0. The optimum $\mathrm{pH}$-value for chitinase enzymes isolated from Gliocladium catenulatum, Stenotrophomonas maltophilia C3 and Alcaligens oxylosoxydans bacteria are found to be $\mathrm{pH}$ 4.0. These studies support the findings obtained in our study. These characteristics are important, because most enzymes are catalytically unstable at asidic $\mathrm{pH}$ values, thus limiting their usefulness in the food industry [18-20].

Standard activity assay was performed at different temperature ranges in order to determine optimum temperature of the chitinase enzyme obtained from isolate of Bacillus subtilis TV-125A. Based on the results obtained, the activity $(\mathrm{EU} / \mathrm{mL})$ was calculated, and the relationship between temperature and activity are given in Figure 4. Optimum temperature value of chitinase enzyme derived from Bacillus subtilis TV-125A was found 


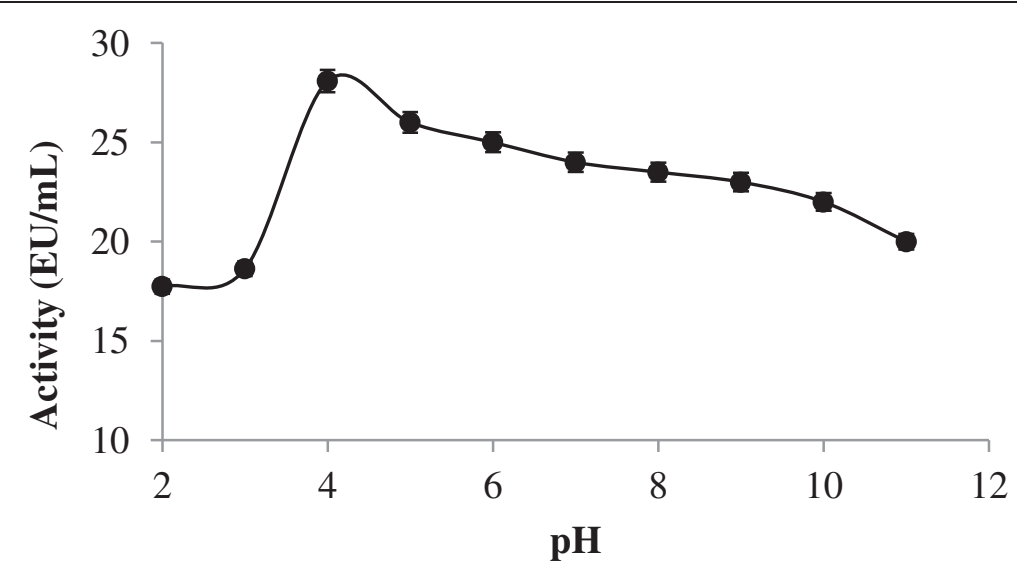

Figure 3 The effect of pH on purified chitinase enzyme activity from Bacillus subtilis TV-125A.

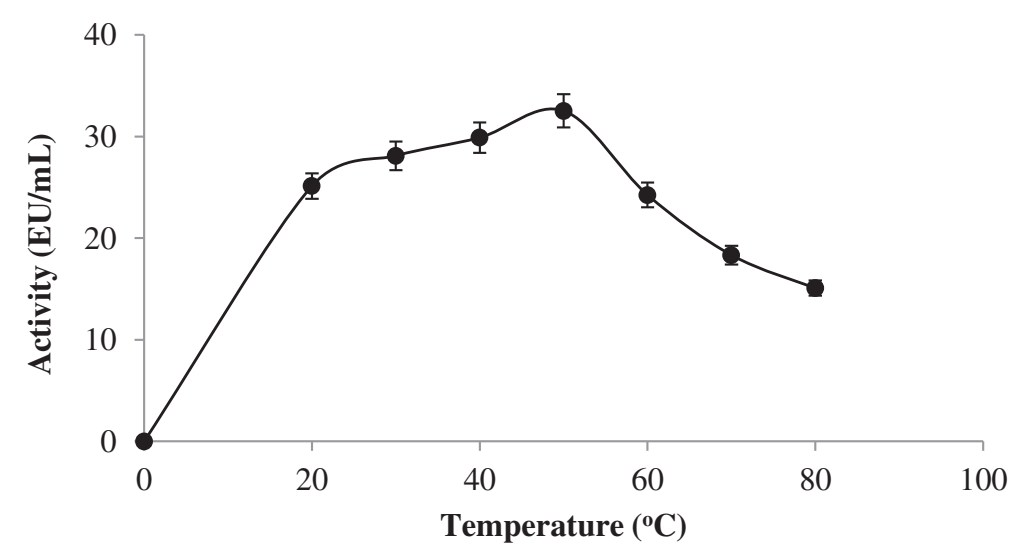

Figure 4 The effect of temperature on purified chitinase enzyme activity from Bacillus subtilis TV-125A.

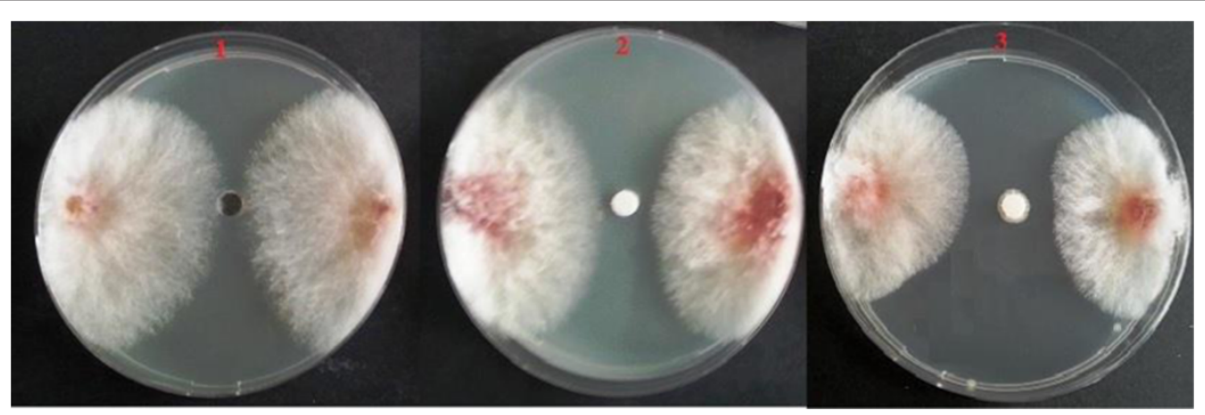

Figure 5 The inhibition effect of purified chitinase enzyme activity from Bacillus subtilis TV-125A on the Fusarium culmorum (1: Control, 2:Homogenate 3: Purified chitinase). 
as $50^{\circ} \mathrm{C}$. At elevated temperature, it was identified that isolates of Bacillus subtilis TV-125A retains its extracellular chitinase enzyme activity to a great extent by $42 \%$ without inhibition (Figure 2).

Yan et al. [21] have reported that Bacillus subtilis SL-13 chitinase enzyme has an optimum activity at $50^{\circ} \mathrm{C}$, Vaidya et al. [20] have reported that Alcaligenes xylosoxoxydans chitinase enzyme has an optimum activity at $50^{\circ} \mathrm{C}$, Bhushan \& Hoondal [22] have reported an optimum activity of Bacillus chitinase enzyme at $45-55^{\circ} \mathrm{C}$, Ghasemi et al. [23] have reported that ChiS chitinase enzyme by the bacterium Bacillus pumilus SG2 has an optimum activity at $50^{\circ} \mathrm{C}$, and Zhang et al. [19] have reported that Stenotrophomonas maltophilia C3 chitinase enzyme showed an optimum activity at $45-50^{\circ} \mathrm{C}$. These results support the findings obtained in our study.

Effective number of isolates and minimum-maximum inhibition zone values of 158 isolates from 9 different species tested in vitro for antifungal properties of the chitinase enzyme partially purified from Bacillus subtilis TV-125A extracellularly in a petri medium against pathogenic fungi are given in Table 1. According to these results, the total 158 isolates were found to form inhibition zones in the range of 12 to $37 \mathrm{~mm}$. It was determined that 10 isolates of Bacillus megaterium species, 8 isolates of Bacillus subtilis species, 6 isolates of Bacillus pumilus species, 2 isolates of Pseudomonas flourescens species, 3 isolates of Pseudomonas putida species, 1 isolate of Paenibacillus macerans species and 1 isolate of Pantoea agglomerans species were effective against the pathogen and prevented development of fungal disc in Petri dish substantially. And, 11 isolates of Bacillus thuringiensis species and 10 isolates of Paenibacillus polymyxa species were found to be ineffective $[21,22]$. The inhibition effect of purified chitinase enzyme activity from Bacillus subtilis TV-125A on the F. culmorum was shown in Figure 5.

\section{Discussion}

Produced chitinase enzyme from Bacillus subtilis TV- 125 which has antifungal activity against $F$. culmorum is expected to be used in the medical field against fungal infections and in agriculture as biocontrol agents. Purified chitinase from Bacillus subtilis TV-125, which is thermostable and active in acidic $\mathrm{pH}$, with a high purification factor and yield, could be an excellent choice in application of food, biotechnology and pharmacology industries.

\section{Competing interests}

The authors declare that they have no competing interests.

\section{Authors' contributions}

This work was carried out in collaboration between all authors. HN designed the study. MS and RK managed the analyses of the study. HN and ND performed the statistical analysis, wrote the protocol, and wrote the first draft of the manuscript, managed the literature searches. All authors read and approved the final manuscript.

\section{Author details}

${ }^{1}$ Department of Biotechnology, Faculty of Agriculture, Ataturk University, 25240 Erzurum, Turkey. ${ }^{2}$ Department of Food Technology, Erzurum Vocational Training School, Ataturk University, 25240 Erzurum, Turkey. ${ }^{3}$ Department of Plant Protect, Faculty of Agriculture, Ataturk University, 25240 Erzurum, Turkey.

Received: 17 May 2014 Accepted: 13 July 2014

Published: 12 August 2014

\section{References}

1. Shahidi F, Arachchi JKV, Jeon YJ: Food applications of chitin and chitosans. Trends Food Sci Tech 1999, 10:37-51.

2. Stryer L: Biochemistry. Thirdth edition. Newyork: W.H. Freeman and Company; 1988.

3. Kumar MNVR: A review of chitin and chitosan applications. React and Funct Polym 2000, 46:1-27.

4. Tanaka T, Fukui T, Atomi H, Imanaka T: Characterization of an exo- $\beta$ Dglucosaminidase involved in a novel chitinolytic pathway from the hyperthermophilic Archaeon thermococcus kodakaraensis KOD 1. J Bacteriol 2003, 185(17):5175-5181.

5. Shen Z, Jacobs-Lorena M: Characterization of a novel gut-specific chitinase gene from the human malaria vector Anopheles gambiae. Biol Chem 1997, 272(46):28895-28900.

6. Sampson MN, Gooday GW: Involvement of chitinases of Bacillus thuringiensis during pathogenesis in insects. Microbiol 1998, 144:2189-2194.

7. Hoell IA, Klemsdal SS, Vaaje-Kolstad G, Horn SJ, Eijsink VGH: Overexpression and characterization of a novel chitinase from Trichoderma atroviride strain P1. BBA-Proteins Proteom 2005, 2:180-190.

8. Kramer KJ, Koga D: Insect chitin. Physioligical state, synthesis, degradation and metabolic regulation. Insect Biochem 1986, 16:851-877.

9. Patil RS, Ghormade V, Deshpande MV: Chitinolytic enzymes: an exploration. Enzyme Microb Technol 2000, 26:473-483.

10. Wen CM, Tseng CS, Cheng CY, Li YK: Purification, characterization and cloning of a chitinase from Bacillus sp. NCTU2. Biotechnol Appl Bioc 2002, 35:213-219.

11. Gooday GW: Diversity of roles for chitinases in nature. In Chitin and Chitosan. Edited by Zakaria MB, Wan Muda WM, Abdullah MP. Malaysia: Penerbit Universiti Kebangsaan; 1995:191-202.

12. Murao S, Kawada T, Itoh H, Oyama H, Shin T: Purification and characterization of a novel type of chitinase from Vibrio alginolyticus. Biosci Biotech Bioch 1992, 56:368-369.

13. Demir A, Seventekin N: Kitin, Kitosan ve Genel Kullanım Alanları. Electronic J of Text Tech 2009, 3(2):92-103.

14. Nadaroglu H, Tasgin E: Purification and Characterisation of Laccase From Lactarius Volemus And Its Application of Removal Phenolic Compounds From Some Fruit Juices. Int J Food Agr Env 2013, 11(3\&4):109-114.

15. Bradford MM: A rapid and sensitive method for the quantition of microgram quantities of protein utilizing the principle of protein-dye binding. Anal Biochem 1976, 72:248-251.

16. Laemmli UK: Cleavage of structural proteins during the assembly of the head of bacteriophage. Nature 1970, 227:680-685.

17. Kotan R, Sahin F, Demirci E, Eken C: Biological control of the potato dry rot caused by Fusarium species using PGPR strains. Biol Control 2009, 50:194-198.

18. Suginta W, Vongsuwan $A$, Songsiriritthigul $C$, Prinz $H$, Estibeiro $P$, Duncan $R R$, Svasti J, Fothergill-Gilmore LA: An endochitinase A from Vibrio carchariae: cloning, expression, mass and sequence analyses, and chitin hydrolysis. Arch Biochem and Biophys 2004, 424:171-180.

19. Zhang Z, Yuen GY, Sarath G, Penheiter AR: Chitinases from the Plant Disease Biocontrol Agent, Stenotrophomonas maltophilia C3. Biol Control 2000, 2:204-211.

20. Vaidya R, Roy S, Macmil S, Gandhi S, Vyas P, Chhatpar HS: Purification and characterization of chitinase from Alcaligenes xylosoxydans. Biotechnol Lett 2003, 25:715-717.

21. Yan $L$, Jing T, Yujun Y, Bin L, Hui L, Chun L: Biocontrol Efficiency of Bacillus subtilis SL-13 and Characterization of an Antifungal Chitinase. Chin J Chem Eng 2011, 19(1):128-134. 
22. Bhushan B, Hoondal GS: Effect of Fungicides, Insecticides and Allosamidin on a Thermostable Chitinase from Bacillus sp. BG-11. World J Microb Bıot 1999, 15:403-404.

23. Ghasemi S, Ahmadian G, Sadeghi M, Zeigler DR, Rahimian H, Ghandilia S, Naghibzadeh N, Dehestani A: First report of a bifunctional chitinase/ lysozyme produced by Bacillus pumilus SG2. Enzyme Microb Tech 2011, 48:225-231.

doi:10.1186/s12941-014-0035-3

Cite this article as: Senol et al:: Purification of Chitinase enzymes from

Bacillus subtilis bacteria TV-125, investigation of kinetic properties and

antifungal activity against Fusarium culmorum. Annals of Clinical

Microbiology and Antimicrobials 2014 13:35.

\section{Submit your next manuscript to BioMed Central and take full advantage of:}

- Convenient online submission

- Thorough peer review

- No space constraints or color figure charges

- Immediate publication on acceptance

- Inclusion in PubMed, CAS, Scopus and Google Scholar

- Research which is freely available for redistribution 